\title{
Impact of Website Characteristics on Online Customer Satisfaction
}

\author{
Hsin-Jung Hsieh \\ Economics \& Management College \\ Zhaoqing University \\ Zhaoqing, China
}

\author{
Li-Ling Yang \\ Economics \& Management College \\ Zhaoqing University \\ Zhaoqing, China
}

\begin{abstract}
Currently, the website characteristics have not been clearly defined or understood, and a proper framework for assessing the status of website characteristics is lacking. The development of a universal model is necessary as a means to measure relevant constructs. This correlational survey research is to explore the relationship between website characteristics and online customer satisfaction. Using a simple random sampling plan, 212 participants from the Yahoo! Shopping website completed an online survey. Multiple regression was used to analyze the data. The hypothesis was partially supported. Findings indicated that information quality, usability, and security/privacy are significant positive explanatory variables of online customer satisfaction. Finally, the researcher provides a discussion of the findings in terms of interpretation, implications, conclusion, and recommendations to this study.
\end{abstract}

Keywords-website characteristics; customer loyality; shopping website

\section{INTRODUCTION}

The development of the Internet and information technology has gradually changed the shopping habits of consumers. Consumers can communicate and trade directly with the online store without being limited by distance and time. The trend has caused many sellers to provide same products in their online stores as well [1]. Due to price competition, online stores only have differences in website platforms and services. Effective website characteristics are considered keys to the success of the online store because they can improve website performance. The website has a variety of characteristics that must be improved to meet customer satisfaction which directly affects purchase intentions [2].

The general purpose of this research is to develop an integrated framework that can explain and guide successful website characteristics. Such a framework may benefit research in website design and also assist online stores in evaluating the effectiveness of their websites. Specific purpose of this correlational research is to explore the relationship between website characteristics and online customer satisfaction.

\section{LITERATURE REVIEW}

\section{A. Website Characteristics}

Regardless of physical or virtual stores, customer interaction with the store environment can affect their emotional response and shopping behavior [3]. In the online shopping process, customers need to use the website platform to obtain information about the products, make judgments based on their existing experience, and then decide whether to purchase. Therefore, the characteristics of shopping websites play an important role in customer purchase decisions. Brun et al. conducted a study to examine the relationship between website characteristics and relationship quality. The study included five website characteristics: convenience, website design, information quality, ease of use, and security/confidentiality [4]. Toufaily et al. investigated social network communities and focused on five website characteristics, which are usability, security/privacy, support quality, customization, and social presence [5]. Tarafdar and Zhang conducted a cross-category study and classified website characteristics into information content, ease of navigation, usability, download speed, personalization, and security [6].

The following further develops the content and theoretical grounding of website characteristics. These primarily focus on information quality, usability, personalization, and security/privacy. Information quality has proven to be a basic requirement for loyal consumers online [7]. Information quality includes accuracy, relevancy, and completeness of the information provided on the website [7]. Moreover, it also should be of appropriate scope and depth and present [6]. Ease of use means that a website should be designed so as to promote effective completion of the tasks associated with it [6]. Usability means that a website is easy to navigate and use [5]. Usability includes the ability to successfully find a page [8]. It also includes the extent to which a website is easy to use, is challenging, visually appealing and fun [9]. Personalization means the website can provide products, services, and purchasing experience that meet the specific needs of customers [10]. Besides, personalization is related to the ability to customize online customer interface, product and service coverage, recommendation, and trading environment [5]. Security implies the website can be described as safe and had 
provisions for executing the secure transactions [9]. Secure websites have the ability to protect their customers form the risk of fraud and financial losses [11].

\section{B. Online Customer Satisfaction}

Online customer satisfaction is one of the most significant consumer reactions in the $\mathrm{B} 2 \mathrm{C}$ online environment [12]. When the online environment exceeds the expectations of customers, they will feel satisfied. Besides expectations, more and more scholars refer that the products and service quality will also affect the customer satisfaction directly [13]. Some scholars believe that online customer satisfaction depends on the evaluation of prior online purchase decisions [2]. Moreover, online customer satisfaction is also an emotional response from the online relationship between the customer and the company [5].

\section{HYPOTHESIS DEVELOPMENT}

The literature review has provided a theoretical framework for this study. The same or similar variables can be explored in the related literature. This study integrated different terminologies used by various authors in describing the website characteristics, considered the website that the researcher wants to study, and then categorized the website characteristics as information quality, usability, personalization, and security/privacy. So far, there have been few studies on website characteristics and online customer satisfaction. Toufaily, Legault, and Richard conducted an empirical study on the relationship between website characteristics and E-satisfaction and posed a theoretical model [5]. The results indicated that website characteristics were significantly related to the E-satisfaction. Therefore, this study hypothesize that there is a significant explanatory relationship between website characteristics (information quality, usability, personalization, and security/privacy) and online customer satisfactory.

"Fig. 1" is a hypothesized model that integrates and depicts the relationships among the major theories and variables in this study.

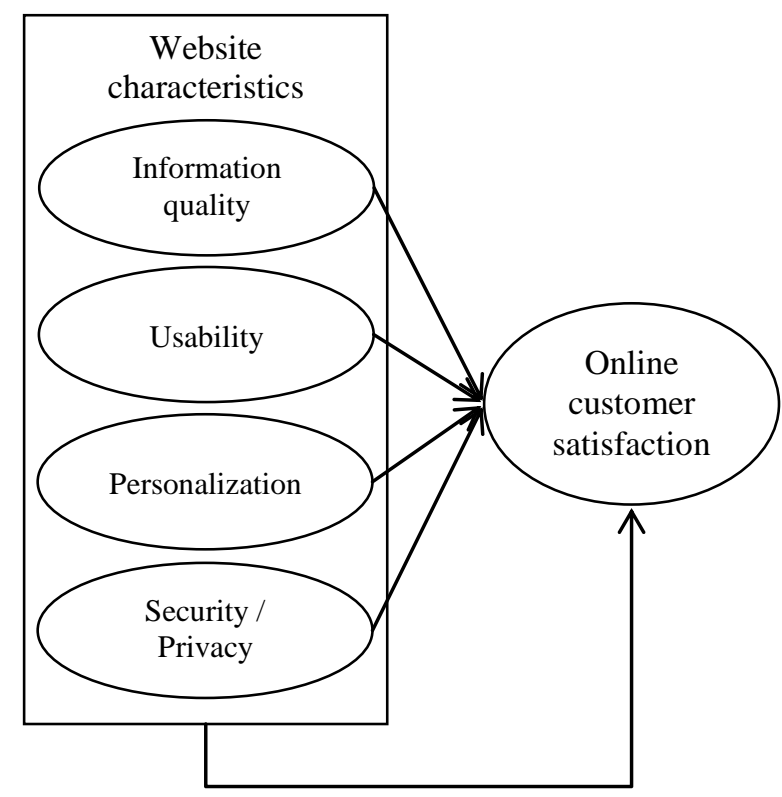

Fig. 1. Hypothesized model.

\section{RESEARCH METHODOLOGY}

In this study, a one-group, randomly selected sample of customers from the Yahoo! Shopping website located in Taiwan was used to test the hypothesis. Data was collected using an online survey. These respondents must have ever shopped on the Yahoo! Shopping website. This resulted in a total of 212 valid responses used in the data analysis procedures.

The three-part, self-report survey was used to collect data Website characteristics were measured using 16 items, and then online customer satisfaction used five items. Respondents were asked to indicate their answers to each item measured by a five-point semantic differential scale, anchored with $1=$ "strongly disagree" and $5=$ "strongly agree". Higher mean scores indicated strong agreement on this item whereas lower mean scores denoted strong disagreement. Personal information was assessed using four items and using a checklist and fill in the blank format.

In this study, exploratory factor analysis was conducted on the scale to further establish construct validity. Coefficient alpha as an estimate of internal consistency reliability was conducted for the scale. An analysis of the descriptive statistics was used for all items. Finally, a correlational research design using multiple regression statistics was used to test the hypothesis.

\section{RESULTS}

\section{A. Exploratory Factor Analysis and Internal Consistency Reliability Analysis}

Principal components analyses using varimax rotation were conducted to test the emergence of four factors. The number of factors actually extracted was determined by the number of items with eigenvalues greater than 1 . For missing 
values, cases were excluded listwise. Factor loadings less than 4 were suppressed and all items loaded onto a factor at 4 or greater as shown in "Table I". The reliability of the website characteristics scale was expressed by Cronbach's coefficient alpha. The coefficient alpha values exceeded the minimum standard of 7, providing good estimates of internal consistency reliability. "Table I" shows that all factors reached an acceptable level of a coefficient alpha: above 7 .

TABLE I. FACTOR LOADINGS AND RELIABILITY

\begin{tabular}{|c|c|c|}
\hline Construct and items & Factor loading & Mean \\
\hline \multicolumn{2}{|l|}{ Information quality (Cronbach's $\alpha=.912$ ) } & 3.70 \\
\hline The information on the Yahoo! Shopping website is accurate. & .651 & 3.94 \\
\hline The information on the Yahoo! Shopping website is useful. & .763 & 3.92 \\
\hline The information on the Yahoo! Shopping website is detailed. & .781 & 3.35 \\
\hline The information on the Yahoo! Shopping website is up to date. & .620 & 3.62 \\
\hline \multicolumn{2}{|l|}{ Usability (Cronbach's $\alpha=.952$ ) } & 3.93 \\
\hline Yahoo! Shopping is very easy to use. & .715 & 3.99 \\
\hline It is easy to navigate and find what I am looking for on the Yahoo! Shopping website. & .877 & 3.98 \\
\hline Yahoo! Shopping is effective for the completion of my tasks. & .745 & 3.92 \\
\hline Yahoo! Shopping is visually appealing. & .649 & 3.88 \\
\hline Yahoo! Shopping is entertaining. & .852 & 3.88 \\
\hline \multicolumn{2}{|l|}{ Personalization (Cronbach's $\alpha=.954)$} & 2.61 \\
\hline Yahoo! Shopping always meets my specific needs. & .810 & 2.47 \\
\hline Yahoo! Shopping has personalization. & .879 & 2.61 \\
\hline Yahoo! Shopping offers personalized information. & .979 & 2.75 \\
\hline \multicolumn{2}{|l|}{ Security / Privacy (Cronbach's $\alpha=.822$ ) } & 3.76 \\
\hline Trading on the Yahoo! Shopping website is safe. & .715 & 3.85 \\
\hline Yahoo! Shopping has provisions for executing the secure transaction. & .691 & 4.09 \\
\hline My personal and financial information is well protected on the Yahoo! Shopping website. & .694 & 3.34 \\
\hline I believe the Yahoo! Shopping website has a good privacy policy. & .698 & 3.77 \\
\hline \multicolumn{2}{|l|}{ Online customer satisfaction (Cronbach's $\alpha=.810$ ) } & 3.48 \\
\hline I am satisfied with the services provided by the Yahoo! Shopping website. & .538 & 3.79 \\
\hline My experience with the Yahoo! Shopping website is pleasant. & .855 & 3.72 \\
\hline Purchasing on the Yahoo! Shopping website is the right decision & .842 & 3.64 \\
\hline I am satisfied with my online relationship with the Yahoo! Shopping website. & .803 & 3.19 \\
\hline Overall, Yahoo! Shopping meets my expectations. & .722 & 3.06 \\
\hline
\end{tabular}

\section{B. Convergent Validity}

Convergent validity was established among all subscales using Pearson $r$ correlation coefficients. As shown in "Table II", significant relationships were found among all subscales.

TABLE II. PEARSON R INTER CORRELATIONS

\begin{tabular}{|c|c|}
\hline & Online Customer Satisfaction \\
\hline Website characteristics & $.454 * * *$ \\
\hline Information quality & $.289 * * *$ \\
\hline Usability & $.596 * * *$ \\
\hline Personalization & $.185 * *$ \\
\hline Security / Privacy & $.510 * * *$ \\
\hline
\end{tabular}

\section{Multiple Regression Analysis}

Multiple regression analysis was employed to examine the relationship between website characteristics variables and online customer satisfaction. The $F$ value (57.857) for the overall regression equation was significant $(\mathrm{p}=.000)$. The adjusted $\mathrm{R} 2$ indicated the regression equation using the three website characteristics variables explained $51.9 \%$ (.519) of the variation in online customer satisfaction. To analyze the individual predictors, the t-statistic, which is the regression coefficient divided by the standard error (SE), was utilized. The results were significant for information quality, usability, and security/privacy. The results for hypothesis testing have been summarized in "Table III" and partially supported the hypothesis is established. (See "Table III") 
TABLE III. SUMMARIZED MULTIPLE REGRESSION ANALYSIS

\begin{tabular}{|c|c|c|c|c|c|}
\hline Variable & B & SE & $\boldsymbol{\beta}$ & $\mathbf{t}$ & $\mathbf{p}$ \\
\hline (Constant) & 2.330 & 1.244 & & & \\
\hline Information quality & .505 & .083 & .450 & 6.118 & .000 \\
\hline Usability & .405 & .038 & .794 & 10.692 & .000 \\
\hline Personalization & .063 & .045 & .073 & 1.389 & .166 \\
\hline Security / Privacy & .382 & .066 & .336 & 5.746 & .000 \\
\hline
\end{tabular}

\section{DISCUSSION AND CONCLUSION}

\section{A. Discussion}

The researcher divided website characteristics into four dimensions, information quality, usability, personalization, and security/privacy. The dimension with the highest rated score was usability, followed by security/privacy, information, and personalization. The item of information quality with the lowest average score was "The information on the Yahoo! shopping website is detailed". The item of usability with the lowest average score was "Yahoo! Shopping is visually appealing" and "Yahoo! Shopping is entertaining". The item of personalization with the lowest average score was "Yahoo! Shopping always meets my specific needs". The item of security/privacy with the lowest average score was "My personal and financial information is well protected on the Yahoo! Shopping website". The item with the lowest online customer satisfaction was "Overall, Yahoo! Shopping meets my expectations".

In terms of the relative importance of these predictors, the order of importance was usability, followed by information quality, and security/privacy. In summary, the overall model was significant in supporting the hypothesis. However, of the four website characteristics, only information quality, usability, and security/privacy were significant and positive explanatory variables of online customer satisfaction. Personalization was not a significant explanatory variable of online customer satisfaction.

\section{B. Conclusion}

In addition to adding to the professional literature, this study helps managers to define their website characteristics more clearly, and to lead their customers more effectively. Some examples of this are now presented.

- To enhance online customer satisfaction, managers could place greater emphasis on improving three dimensions: usability, information quality, and security/privacy. If websites are easy to use and find information for users, personalization may not be a key factor in improving satisfaction.

- The websites should provide more detailed information to consumers. After all, consumers cannot directly see the goods or ask for product information. Detailed product information can give online shoppers more confidence.

- Web designers should make webpages more interesting and attractive. When customers find website entertaining, their interaction with the site will increase and they will have a positive attitude towards the site.

- Many online customers do not believe that the website will properly protect their personal information. This research finds that online customer protection against fraud and infringement of privacy will affect online customer satisfaction.

As this study was conducted in Taiwan, the findings may only be generalized to similar Taiwan shopping websites but cannot be generalized to other groups, industries or areas. Future research can be conducted in different industries or countries. Future studies may add other variables, such as customer loyalty and web performance and make the model more complete.

\section{REFERENCES}

[1] H. Adnan. "An Analysis of the Factors Affecting Online Purchasing Behavior of Pakistani Consumers," International Journal of Marketing Studies, 6:5, 2014, pp. 133-148.

[2] K. Abrar, S. Zaman, and Z. W. Satti. "Impact of Online Store Atmosphere, Customized Information and Customer Satisfaction on Online Repurchase Intention," GMJACS, 7:2, 2017, pp. 22-34.

[3] V. Mummalaneni. "An Empirical Iinvestigation of Web Site Characteristics, Consumer Emotional States and On-line Shopping Behaviours," Journal of Business Research, 58:4, 2005, pp. 526-532.

[4] I. Brun, L. Rajaobelina, L. Richard, and A. Fortin. "Impact of Website Characteristics on Relationship Quality: A Comparison of Banks Financial Cooperatives," Journal of Financial Services Marketing, 22:4, 2017, pp. 141-149.

[5] E. Toufaily, M. Arcand, J. Legault, and L. Ricard. "The Roles of Website Characteristics and Social Network Communities in Developing Customer E-loyalty in the Online Travel Industry," Journal of Tourism \& Hospitality, 5:3, 2016, pp. 222-233.

[6] M. Tarafdar and J. Zhang. "Analysis of Critical Website Characteristics: A Cross-category Study of Successful Websites," Journal of Computer Information Systems, 46:2, 2006, pp. 15-24.

[7] R. Ladhari and A. Leclerc. "Building Loyalty with Online Financial Services Customers: Is There a Gender Difference?," Journal of Retailing and Consumer Services, 20:6, 2013, pp. 56-59.

[8] Y.D. Wang and H.H. Emurian. "An Overview of Online Trust: Concepts, Elements, and Implications," Computers in Human Behavior, 21:1, 2005, p.p. 105-125.

[9] M. Tarafdar and J. Zhang. "Determinants of Reach and Loyalty - A Study of Website Performance and Implications for Website Design," Journal of Computer Information Systems, 48:2, 2008, pp. 16-24.

[10] S.S. Srinivasan, R.E. Anderson, and K. Ponnavolu. "Customer Loyalty in E-commerce: An Exploration of its Antecedents and Consequences," Journal of Retailing, 78:1, 2002, pp. 279-295.

[11] R. Law, S. Qi, and D. Buhalis. "Progress in Tourism Management: A Review of Website Evaluation in Tourism Research," Tourism Management, 31:3, 2010, pp. 297-313.

[12] C.M. Cheung and M.K. Lee. "The Asymmetric Effect Of Web Site Attribute Performance On Web Satisfaction: An Empirical Study," Eservice Journal, 3:3, 2005, pp. 65-86.

[13] T. Sheng and C. Liu. "An Empirical Study on the Effect of E-service Quality on Online Customer Satisfaction and Loyalty," Nankai Business Review International, 1:3, 2010, pp. 273-283. 